Article

\title{
Climatic Factors Shape the Spatial Distribution of Concentrations of Triterpenoids in Barks of White Birch (Betula Platyphylla Suk.) Trees in Northeast China
}

\author{
Shenglei Guo ${ }^{1}$, Dehui Zhang ${ }^{2,3}$, Huanyong Wei ${ }^{2,3}$, Yinan Zhao ${ }^{2,3}$, Yibo Cao ${ }^{2,3}$, Tao Yu ${ }^{2,3}$, \\ Yang Wang ${ }^{2,3}$ and Xiufeng Yan ${ }^{2,3, *}$ \\ 1 College of Pharmacy, Heilongjiang University of Chinese Medicine, Harbin 150040, China; \\ guoshenglei@163.com \\ 2 Alkali Soil Natural Environmental Science Center, Northeast Forestry University, Harbin 150040, China; \\ zhangdehui1984@sina.com (D.Z.); weihuanyong2001@163.com (H.W.); zhaoyn.happy@sina.com (Y.Z.); \\ caoyibo2010@sina.com (Y.C.); YT19930617@sina.com (T.Y.); ywang1971@hotmail.com (Y.W.) \\ 3 Key Laboratory of Saline-alkali Vegetation Ecology Restoration in Oil Field, Northeast Forestry University, \\ Harbin 150040, China \\ * Correspondence: xfyan@nefu.edu.cn; Tel.: +86-451-8219-0052
}

Received: 22 July 2017; Accepted: 6 September 2017; Published: 10 September 2017

\begin{abstract}
Betulin, betulinic acid and lupeol are naturally occurring pentacyclic triterpenoids with significant medicinal values. Great amounts of triterpenoids are found in the bark of white birch (Betula platyphylla Suk.) trees, which can be affected by climatic factors along the geographical gradients. In this study, site-based data of triterpenoids' (betulin, betulinic acid and lupeol) concentrations were determined in barks of white birch trees from 48 sites in Northeast China. Triterpenoid concentration in white birch tree barks did not change in response to any geographical gradients along latitudes, longitudes or elevations. Instead, concentrations of betulin and lupeol in birch tree barks increased with the increase of temperature and precipitation but declined with the increase of relative humidity. As a result, betulin concentration was higher in birch trees in the northeastern and southwestern parts of the study area, and lower in the central part of the study area in Northeast China. Although betulinic acid concentration did not change with climatic factors, its distribution pattern was similar to betulin concentration. Lupeol concentration was highest in the north-eastern part and along the southern and eastern boundaries in the study area. Our results can supply information for precondition of triterpenoids' extraction for industrial production, which can be an available approach to solve the issue of bark waste processing of white birch.
\end{abstract}

Keywords: natural product; climate change; transect; montane area; microclimate

\section{Introduction}

The white birch is widespread in the northern latitudes of the world and represents an abundant and currently under-utilized natural resource [1]. Birch tree bark (BTB) is not only a kind of large-scale timber-processing waste but also a source of valuable extractive components [2]. Triterpenoid is one of main extractive components from BTB which may account for up to 30\% (weight percent) of the dry mass in exfoliated narrow foils. Triterpenoid compounds are abundant in natural sources and have a wide variety of pharmacological uses. Mostly, triterpenoids are extracted to develop new anticancer drugs [3]. Betulin $\left(\mathrm{C}_{30} \mathrm{H}_{50} \mathrm{O}_{2}\right)$ and betulinic acid $\left(\mathrm{C}_{30} \mathrm{H}_{48} \mathrm{O}_{3}\right)$ are naturally occurring pentacyclic triterpenoids that have significant cosmetic, medicinal and economic values [4-7]. Betulin is a component of cosmetic powders and other cosmetic products [5]. Betulin can be used to inhibit the 
ethanol-induced cytokine production of superoxide anion [8,9], for its anti-inflammatory activity [10], its antiviral efficacy [11,12] and anticonvulsant activity [13]. Betulinic acid is the oxidation product of botulin and has been found to have specified efficacies of anti-tumor, anti-inflammatory and anti-HIV virtues [11,14]. Lupeol (3 $\beta$-hydroxylup-20(29)-ene) is an immense bioactive compound, which also has broad pharmacological uses and can be used for the development of anti-oxidative and anti-inflammatory drugs [15]. Lupeol content has also been found to be well documented by the interaction between birch tree vigor and decay proportion [16]. All three of these triterpenoids can be synthesized and accumulated in BTB [6]. Therefore, determining the reserves of triterpenoids in BTB can supply precondition of triterpenoids' extraction for industrial production, which can be an available approach to solve the issue of bark waste processing of white birch.

Some studies found that content of triterpenoids can vary to a great extent in BTB in different locations [1,14]. Zhao et al. reported that betulin ranged between $11.3 \%$ and $20.22 \%$, and betulinic acid ranged between $1.22 \%$ and $1.86 \%$ in Northeast China [1]. Holonec et al. reported that botulin concentration ranged between 145.63 and $165.60 \mathrm{mg} \mathrm{g}^{-1}$ and betulinic acid ranged between 14.68 and $15.44 \mathrm{mg} \mathrm{g}^{-1}$ in the Western Carpathians, Romania [14]. The geographical distribution of triterpenoids may be shaped by the combined effects of exogenous factors. Yin et al. found that some environmental factors can specially affect the accumulation of botulin through modifying the OSC gene expression in white birch [17]. These studies together indicated that climatic factors in different regions may have driven the response of triterpenoid accumulation in birch trees at different regions. The triterpenoid deposition is a response to high temperature shock because it can prevent thermal damage to the highly ordered aliphatic wax barrier in desert plants even at high temperatures [18]. Low temperatures can also affect the accumulation of triterpenoids in Gentiana straminea [19]. Drought stress has been found to promote the synthesis of triterpenoids in Glycyrrhiza glabra [20] and birch [17]. Hence, current knowledge is mainly from laboratory manipulations, and little is known about the relationship between climatic factors and triterpenoid concentration in birch trees distributed in different regions at a large geographical scale.

The white barked birch (Betula platyphylla Suk) is widespread in Northeast China, which represents an abundant and currently underutilized natural resource. In the present study, betulin, betulinic acid and lupeol were chosen as the objective triterpenoids and their concentrations in birch bark were elucidated to make clear its relationship to climatic factors of temperature, moisture and precipitation in sites. Data were collected based on the field survey from 48 sampling sites in Xing'an Mountains and Changbai Mountains across Heilongjiang and Jilin Provinces, Northeast China. The overall aim of this study was to find answers to scientific questions: (1) at what level were concentrations of three triterpenoids in BTB in the study area; (2) what were the spatial patterns of concentrations of three triterpenoids; and (3) what was the relationship between three triterpenoids and climatic factors. This study can provide useful information about how to manage the white-barked birch to efficiently utilize triterpenoids from natural sources in white birch bark.

\section{Materials and Methods}

\subsection{Study Area}

The current study was performed in northeast China $\left(38^{\circ} 41^{\prime}-53^{\circ} 33^{\prime} \mathrm{N}, 118^{\circ} 50^{\prime}-135^{\circ} 4^{\prime} \mathrm{E}\right)$. The study area covers Heilongjiang and Jilin Provinces with a total geographical area of $7.9 \times 105 \mathrm{~km}^{2}$. The landscape is characterized by plains and mountains with elevations ranging from 3 to $1017 \mathrm{~m}$. The annual temperature varies between $-4.7^{\circ} \mathrm{C}$ and $10.7^{\circ} \mathrm{C}$, and annual precipitation ranges from 400 to $900 \mathrm{~mm}$. The precipitation is distributed mainly in the crop-growing season from April to August. The mean precipitation during this period ranges from $338 \mathrm{~mm}$ per year in the northwest to $866 \mathrm{~mm}$ per year in the southeast. The summer precipitation varies from 290 to $533 \mathrm{~mm}$ per year, accounting for $78 \%$ of the total precipitation during the plant-growing season. 


\subsection{Study Sites and Sample Collection}

The following criteria were used for birch tree site determination: all sites were part of pure birch forests (the coverage of birch trees was over $80 \%$ ) and represent the early successional development stage. Following a survey, 45 sites were chosen in regions of Xing' an Mountain in Heilongjiang Province and Changbai Mountain in Jilin Province, China with three additional sites located in urbanized regions of Inner Mongolia Autonomous Region (Table 1). Therefore, data for BTB triterpenoid concentrations can represent the large-scale patterns of distribution across three main forest types in Northeast China (Figure 1). The white birch bark samples were collected in the 48 sites from June to July in 2009 and 2010. In each site, barks were collected from 20-30 adult trees and 15-20 cm in diameter at breast height (DBH, $1.3 \mathrm{~m}$ above the ground). Exfoliated narrow foils of $5 \mathrm{~cm}$ in length and width were sampled. A forest inventory was conducted in each site and the weight of the triterpenoids per square meter in the white birch bark were calculated by selecting median trees for estimating the amounts of the triterpenoids per tree and per hectare.

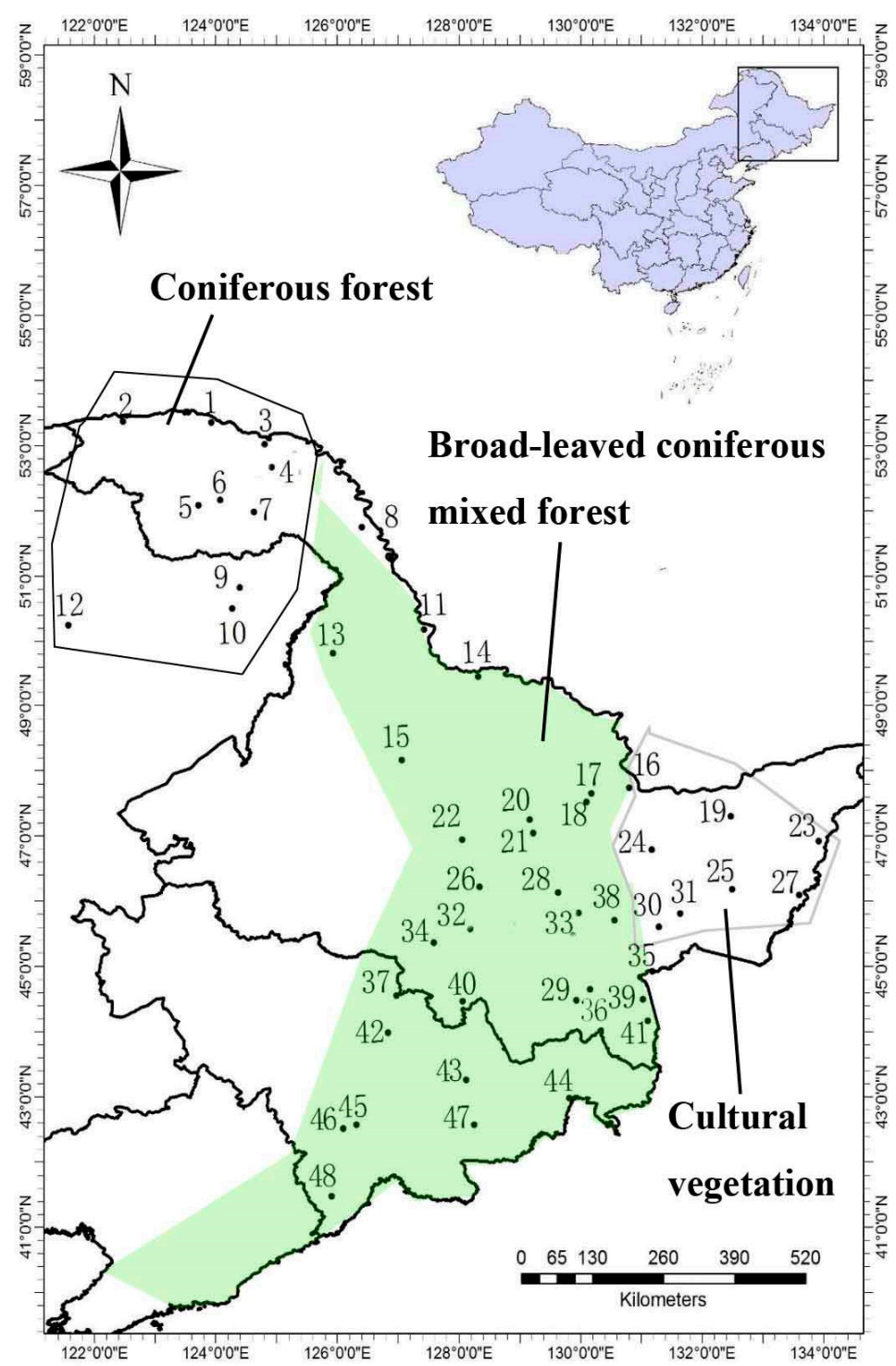

Figure 1. Map of the 48 investigating plots of naturally distributed birch trees in the Xing'an Mountain and the Changbai Mountain in Northeast China and Inner Mongolia Autonomous Region. Plots were numbered in the same order of field data collection. 
Table 1. Geographical distribution of 48 sampling plots of birch trees for triterpenoid extracts in Xing'an Mountains and Changbai Mountains, Northeast of China.

\begin{tabular}{|c|c|c|c|c|c|c|c|}
\hline No. & Plot Name & Coordinates & $\begin{array}{l}\text { Altitude } \\
\text { (m) }\end{array}$ & No. & Plot Name & Coordinates & $\begin{array}{l}\text { Altitude } \\
\text { (m) }\end{array}$ \\
\hline 1 & Amuer & $\begin{array}{l}53^{\circ} 22^{\prime} \mathrm{N} \\
123^{\circ} 50^{\prime} \mathrm{E}\end{array}$ & 424 & 25 & Baoqing & $\begin{array}{r}46^{\circ} 7^{\prime} \mathrm{N} \\
132^{\circ} 26^{\prime} \mathrm{E}\end{array}$ & 271 \\
\hline 2 & Mohe & $\begin{array}{l}53^{\circ} 14^{\prime} \mathrm{N} \\
122^{\circ} 13^{\prime} \mathrm{E}\end{array}$ & 705 & 26 & Mulan & $\begin{array}{l}46^{\circ} 4^{\prime} \mathrm{N} \\
128^{\circ} 6^{\prime} \mathrm{E}\end{array}$ & 143 \\
\hline 3 & Kaikukang & $\begin{array}{l}53^{\circ} 6^{\prime} \mathrm{N} \\
124^{\circ} 43^{\prime} \mathrm{E}\end{array}$ & 284 & 27 & Hulin & $\begin{array}{l}45^{\circ} 59^{\prime} \mathrm{N} \\
133^{\circ} 35^{\prime} \mathrm{E}\end{array}$ & 62 \\
\hline 4 & Tahe & $\begin{array}{l}52^{\circ} 32^{\prime} \mathrm{N}, \\
124^{\circ} 44^{\prime} \mathrm{E}\end{array}$ & 657 & 28 & Yilan & $\begin{array}{l}45^{\circ} 59^{\prime} \mathrm{N} \\
129^{\circ} 38^{\prime} \mathrm{E}\end{array}$ & 118 \\
\hline 5 & Huzhong & $\begin{array}{l}52^{\circ} 5^{\prime} \mathrm{N} \\
123^{\circ} 35^{\prime} \mathrm{E}\end{array}$ & 529 & 29 & Boli & $\begin{array}{l}45^{\circ} 41^{\prime} \mathrm{N} \\
130^{\circ} 19^{\prime} \mathrm{E}\end{array}$ & 542 \\
\hline 6 & Hanjiayuan & $\begin{array}{r}52^{\circ} 4^{\prime} \mathrm{N} \\
123^{\circ} 50^{\prime} \mathrm{E}\end{array}$ & 851 & 30 & Qitaihe & $\begin{array}{l}45^{\circ} 36^{\prime} \mathrm{N} \\
131^{\circ} 17^{\prime} \mathrm{E}\end{array}$ & 611 \\
\hline 7 & Xinlin & $\begin{array}{l}51^{\circ} 53^{\prime} \mathrm{N} \\
124^{\circ} 31^{\prime} \mathrm{E}\end{array}$ & 538 & 31 & Mishan & $\begin{array}{l}45^{\circ} 35^{\prime} \mathrm{N} \\
131^{\circ} 27^{\prime} \mathrm{E}\end{array}$ & 273 \\
\hline 8 & Huma & $\begin{array}{l}51^{\circ} 49^{\prime} \mathrm{N} \\
126^{\circ} 29^{\prime} \mathrm{E}\end{array}$ & 309 & 32 & Yanshou & $\begin{array}{c}45^{\circ} 34^{\prime} \mathrm{N}, 128^{\circ} \\
\mathrm{E}\end{array}$ & 223 \\
\hline 9 & Songling & $\begin{array}{l}50^{\circ} 50^{\prime} \mathrm{N} \\
124^{\circ} 13^{\prime} \mathrm{E}\end{array}$ & 464 & 33 & Linkou & $\begin{array}{l}45^{\circ} 34^{\prime} \mathrm{N} \\
129^{\circ} 56^{\prime} \mathrm{E}\end{array}$ & 445 \\
\hline 10 & Cuifeng & $\begin{array}{l}50^{\circ} 20^{\prime} \mathrm{N} \\
124^{\circ} 7^{\prime} \mathrm{E}\end{array}$ & 415 & 34 & Maoershan & $\begin{array}{l}45^{\circ} 22^{\prime} \mathrm{N} \\
127^{\circ} 33^{\prime} \mathrm{E}\end{array}$ & 687 \\
\hline 11 & Heihe & $\begin{array}{l}50^{\circ} 5^{\prime} \mathrm{N} \\
127^{\circ} 31^{\prime} \mathrm{E}\end{array}$ & 126 & 35 & Jixi & $\begin{array}{l}44^{\circ} 54^{\prime} \mathrm{N} \\
131^{\circ} 1^{\prime} \mathrm{E}\end{array}$ & 657 \\
\hline 12 & Kuduer & $\begin{array}{l}50^{\circ} 1^{\prime} \mathrm{N} \\
121^{\circ} 28^{\prime} \mathrm{E}\end{array}$ & 1082 & 36 & Daimagou & $\begin{array}{l}44^{\circ} 34^{\prime} \mathrm{N} \\
130^{\circ} 2^{\prime} \mathrm{E}\end{array}$ & 712 \\
\hline 13 & Nenjiang & $\begin{array}{l}49^{\circ} 38^{\prime} \mathrm{N} \\
125^{\circ} 49^{\prime} \mathrm{E}\end{array}$ & 418 & 37 & Yushu & $\begin{array}{l}44^{\circ} 32^{\prime} \mathrm{N}, \\
126^{\circ} 56^{\prime} \mathrm{E}\end{array}$ & 216 \\
\hline 14 & Xunke & $\begin{array}{l}49^{\circ} 27^{\prime} \mathrm{N} \\
128^{\circ} 8^{\prime} \mathrm{E}\end{array}$ & 170 & 38 & Sidao & $\begin{array}{l}44^{\circ} 28^{\prime} \mathrm{N} \\
129^{\circ} 49^{\prime} \mathrm{E}\end{array}$ & 467 \\
\hline 15 & Bei'an & $\begin{array}{l}47^{\circ} 59^{\prime} \mathrm{N} \\
126^{\circ} 50^{\prime} \mathrm{E}\end{array}$ & 286 & 39 & Suifenhe & $\begin{array}{l}44^{\circ} 28^{\prime} \mathrm{N} \\
131^{\circ} 8^{\prime} \mathrm{E}\end{array}$ & 724 \\
\hline 16 & Luobei & $\begin{array}{l}47^{\circ} 45^{\prime} \mathrm{N} \\
130^{\circ} 48^{\prime} \mathrm{E}\end{array}$ & 281 & 40 & Shanhetun & $\begin{array}{l}44^{\circ} 24^{\prime} \mathrm{N} \\
127^{\circ} 51^{\prime} \mathrm{E}\end{array}$ & 392 \\
\hline 17 & Hegang & $\begin{array}{l}47^{\circ} 25^{\prime} \mathrm{N} \\
130^{\circ} 10^{\prime} \mathrm{E}\end{array}$ & 193 & 41 & Dongning & $\begin{array}{l}44^{\circ} 11^{\prime} \mathrm{N} \\
131^{\circ} 12^{\prime} \mathrm{E}\end{array}$ & 682 \\
\hline 18 & Helin & $\begin{array}{l}47^{\circ} 23^{\prime} \mathrm{N} \\
130^{\circ} 1^{\prime} \mathrm{E}\end{array}$ & 290 & 42 & Jilin & $\begin{array}{l}43^{\circ} 46^{\prime} \mathrm{N} \\
126^{\circ} 43^{\prime} \mathrm{E}\end{array}$ & 428 \\
\hline 19 & Fujin & $\begin{array}{l}47^{\circ} 13^{\prime} \mathrm{N} \\
132^{\circ} 16^{\prime} \mathrm{E}\end{array}$ & 418 & 43 & Dunhua & $\begin{array}{l}43^{\circ} 14^{\prime} \mathrm{N}, \\
128^{\circ} 2^{\prime} \mathrm{E}\end{array}$ & 663 \\
\hline 20 & Nancha & $\begin{array}{l}47^{\circ} 8^{\prime} \mathrm{N} \\
129^{\circ} 5^{\prime} \mathrm{E}\end{array}$ & 210 & 44 & Tumen & $\begin{array}{l}42^{\circ} 53^{\prime} \mathrm{N} \\
129^{\circ} 43^{\prime} \mathrm{E}\end{array}$ & 378 \\
\hline 21 & Dailing & $\begin{array}{l}47^{\circ} 3^{\prime} \mathrm{N} \\
129^{\circ} 0^{\prime} \mathrm{E}\end{array}$ & 324 & 45 & Huadian & $\begin{array}{l}42^{\circ} 31^{\prime} \mathrm{N} \\
126^{\circ} 14^{\prime} \mathrm{E}\end{array}$ & 361 \\
\hline 22 & Tieli & $\begin{array}{l}46^{\circ} 52^{\prime} \mathrm{N} \\
128^{\circ} 2^{\prime} \mathrm{E}\end{array}$ & 225 & 46 & Jingyu & $\begin{array}{l}42^{\circ} 26^{\prime} \mathrm{N} \\
126^{\circ} 4^{\prime} \mathrm{E}\end{array}$ & 434 \\
\hline 23 & Raohe & $\begin{array}{l}46^{\circ} 47^{\prime} \mathrm{N} \\
133^{\circ} 51^{\prime} \mathrm{E}\end{array}$ & 192 & 47 & Changbai & $\begin{array}{l}42^{\circ} 24^{\prime} \mathrm{N} \\
128^{\circ} 6^{\prime} \mathrm{E}\end{array}$ & 774 \\
\hline 24 & Jixian & $\begin{array}{l}46^{\circ} 38^{\prime} \mathrm{N} \\
130^{\circ} 59^{\prime} \mathrm{E}\end{array}$ & 296 & 48 & Tonghua & $\begin{array}{l}41^{\circ} 2^{\prime} \mathrm{N} \\
125^{\circ} 16^{\prime} \mathrm{E}\end{array}$ & 325 \\
\hline
\end{tabular}

\subsection{Climatic Data Collection}

Climatic factors of temperature, precipitation and humidity were chosen as the parameters and yearly data were obtained from the China Meteorological Data Service Center [21]. Climatic data were downloaded from records by climate stations near each of the 48 sampling sites for the period of 1960-2009 in Northeast China. These selected climate stations were uniformly distributed across Northeast China, covering 13 degrees of latitude $\left(38-51^{\circ} \mathrm{N}\right)$ and had a range of 3.3-775 $\mathrm{m}$ in altitude. The climatic records have been assessed by China Meteorological Administration (CMA) to assure 
consistency, continuity, and quality by taking into account instrument location and relocation of the station. The coordinates and elevation of each sampling site's location was recorded by using a global positioning system (GPS) with an accuracy of $1 \mathrm{~m}$, which was used to extract geographical data of each sampling site.

\subsection{Extraction and Determination of Triterpenoids}

Both methods of extraction and determination of triterpenoids were adapted and modified from Wang et al. [6]. Bark samples were cut into pieces and ground into powders for 10 min with the presence of liquid nitrogen $(\mathrm{N})$. Smashed samples were passed through a 40-mesh screen and incubated in flasks by a ventilated-oven (WG71 Electric Thermostats, Taisite, Tianjin, China) at $80{ }^{\circ} \mathrm{C}$ until weight was unchanged. Dried samples were moved to $10-\mathrm{mL}$ stoppered conical flask and extracted in $10 \mathrm{~mL}$ ethanol $(95 \%, v / v)$ with ultrasonic bath (Shumei, Kunshan, China) at $40 \mathrm{~Hz}$. The extracts were filtered through $0.45 \mu \mathrm{m}$ membranes and reserved at $0-4{ }^{\circ} \mathrm{C}$.

The determination was performed using a HPLC system (Water, Milford, MA, USA) consisting of a Waters 600 Multisovent Delivery System, a Waters 2707 Autosampler, a Waters Analytical Column Oven, and a Waters 2996 PDA Detector. HPLC-grade acetonitrile (J.T. Barker, Philipsburg, NJ, USA) was employed. Data were gathered and processed using Empower 3 Chromatography Data Software.

Standard substances of betulin, betulinic acid and lupeol were purchased from Sigma-Aldrich Chemical Corporation (Sigma, St. Saint Louis, MO. USA). Standard substances were dissolved respectively in High Performance Liquid Chromatography (HPLC)-grade ethanol as mother liquors in concentrations of $2.5 \mathrm{mg} \mathrm{mL}^{-1}$ for betulin and $1 \mathrm{mg} \mathrm{mL}^{-1}$ for both betulinic acid and lupeol. Solutions were filtered through $0.45 \mu \mathrm{m}$ organic liquid membranes and diluted to the volume of $3000 \mu \mathrm{g} \mathrm{mL}^{-1}$ for betulin, $300 \mu \mathrm{g} \mathrm{mL}^{-1}$ for betulinic acid and $1200 \mu \mathrm{g} \mathrm{mL}^{-1}$ for lupeol. Standard solutions and samples were both injected into the chromatograph for determination. The chromatographic peaks of objective compounds were confirmed by matching the retention time and UV wavelength. Quantification was carried out by integration of the peaks using the external standard method for calculation of correlation coefficients $\left(r^{2}\right)$, limit of detection (LOD) and limit quantity (LOQ).

\subsection{Statistical Analysis}

Concentrations of triterpenoids in BTB were interpolated by kriging using ArcGIS software version 9.3 (Esri China Information Technology Co. Ltd., Beijing, China) to generate their spatial patterns in the study area of Northeast China. Statistical correlations were detected with climatic indices (i.e., temperature, precipitation and humidity) and geographical indices (i.e., longitude, latitude and elevation) of sampling sites as independent variables, and concentrations of triterpenoids as dependent variables. Both Pearson and Spearman correlation models were employed to ensure either linear or non-linear correlation can be found. When significant correlation was indicated, dependent and independent variables were used to find the fit curve and fit model parameters for scattered plots using Sigmaplot v. 12.0 (Systat Software Inc., San Jose, CA, USA). Stepwise linear correlations were carried out to detect the geographical and climatic variables accounting for the most variations of data with the statistical software of SPSS v. 19.0 (IBM Analytics Inc., New York, NY, USA).

\section{Results}

\subsection{General Description of Data About Geographical and Climatic Factors}

All sites in our study locate between latitudes $41^{\circ}$ and $53^{\circ} \mathrm{N}$ (Table 2) where most lands are covered by deciduous broad-leaved forest and coniferous forest (Figure 1). Site altitudes ranged from $60 \mathrm{~m}$ to $1000 \mathrm{~m}$ (Table 1). Annual temperature was lower than that of the whole area of Northeast China (5.6-9.4 $\left.{ }^{\circ} \mathrm{C}\right)$ because most of our sites are located in montane areas with few urbanized lands. Relative humidity is higher than that of urban environments of Northeast China ( 40\%) because montane precipitation falls into the high level of regional rainfall records. The maximum concentration 
values of betulin and betulinic acid were moderately higher than the minimum concentration values by $102 \%$ and $247 \%$, respectively (Table 2). However, the variation of lupeol concentration values was greater than that of betulin and betulinic acid and the maximum value was 4.7-fold higher than the minimum one.

Table 2. Descriptive analysis of geographical indices, climatic factors and triterpenoid concentrations in birch tree bark and geographical and climatic indices for 48 sampling plots in Northeast China.

\begin{tabular}{|c|c|c|c|c|}
\hline Parameters & Max & Min & Mean & S.E. \\
\hline \multicolumn{5}{|c|}{ Geographical indices } \\
\hline Latitude $\left(^{\circ}\right)$ & 53.24 & 41.04 & 47.07 & 3.25 \\
\hline Longitude $\left({ }^{\circ}\right)$ & 133.9 & 121.5 & 128.07 & 2.98 \\
\hline Elevation (m) & 1082 & 62 & 422.39 & 220.31 \\
\hline \multicolumn{5}{|c|}{ Climatic factors } \\
\hline Temperature $\left({ }^{\circ} \mathrm{C}\right)$ & 6 & -3.9 & 2.15 & 2.68 \\
\hline Relative humidity (\%) & 80 & 55 & 66.89 & 4.69 \\
\hline Precipitation (mm) & 893.6 & 384.7 & 567.5 & 103.98 \\
\hline \multicolumn{5}{|c|}{ Climatic factors } \\
\hline Betulin $\left(\mathrm{mg} \mathrm{g}^{-1}\right)$ & 343.05 & 169.77 & 239.114 & 6.267 \\
\hline Betulinic acid ( $\left.\mathrm{mg} \mathrm{g}^{-1}\right)$ & 45.36 & 13.07 & 28.905 & 0.973 \\
\hline Lupeol $\left(\mathrm{mg} \mathrm{g}^{-1}\right)$ & 6.4 & 1.13 & 3.354 & 0.166 \\
\hline
\end{tabular}

S.E.: Standard error.

\subsection{Spatial Distribution of Climatic Factors}

Temperature declined with the increase of latitude degree in the study area (Figure 2a). Nearly $60 \%$ of the study area has an annual temperature of $0-6{ }^{\circ} \mathrm{C}$. Relative humidity did not show an apparent latitudinal pattern across the study area (Figure $2 b$ ). Instead, relative humidity tended to be higher in the west of the study area, decreased in the central area, and increased again in the eastern part. Like the geographical change of temperature, precipitation also declined with the increase of latitude degree (Figure 2c).
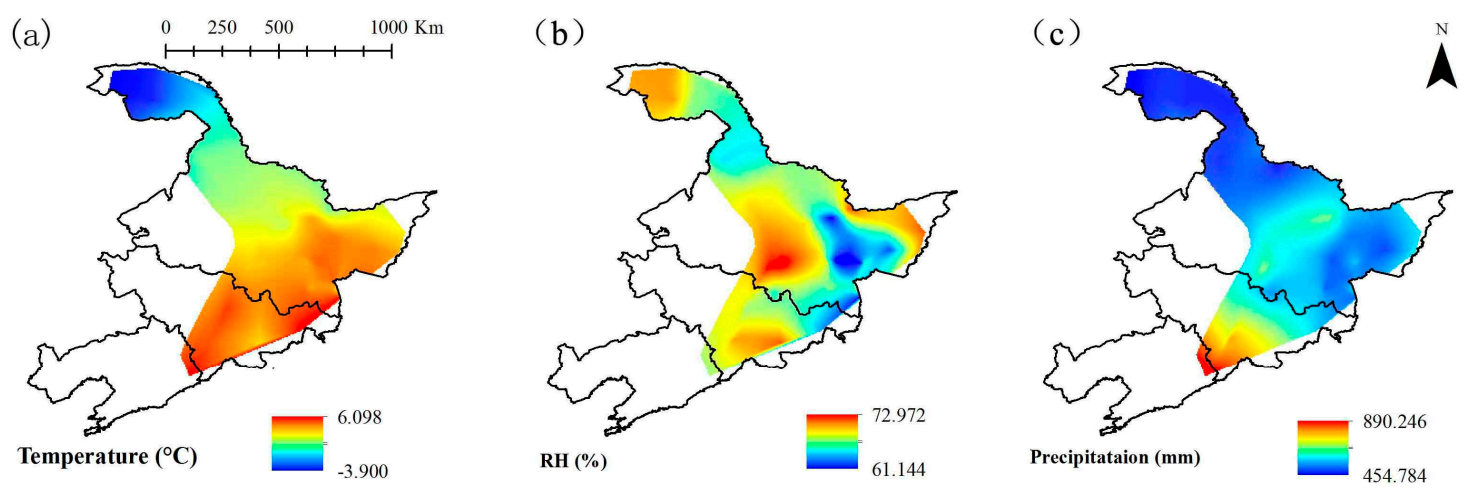

Figure 2. Spatial distributions of climatic factors of temperature (a), relative humidity (RH) (b) and precipitation (c) from 48 sampling plots for bark collection from white birch trees in Northeast China.

\subsection{Spatial Distribution of Concentrations of Three Triterpenoids}

White birch trees distributed in the northeastern and southwestern parts of the study area generally had higher concentrations of betulin and betulinic acid in barks than those in other parts (Figure 3a,b). Lupeol concentration in barks of white birch trees was higher in the northeastern part of the study area and along the southern and eastern boundaries of the study area. White birch trees in the northern part of the study area had the lowest concentration of three triterpenoids, while those in 
the central part of the study area, that is, the southern area of Heilongjiang Province and the northeast area of Jilin Province, also had low concentrations of triterpenoids; this was despite the fact that the low concentration area of betulinic acid was much smaller than that of the other two triterpenoids (Figure 3).

(a)

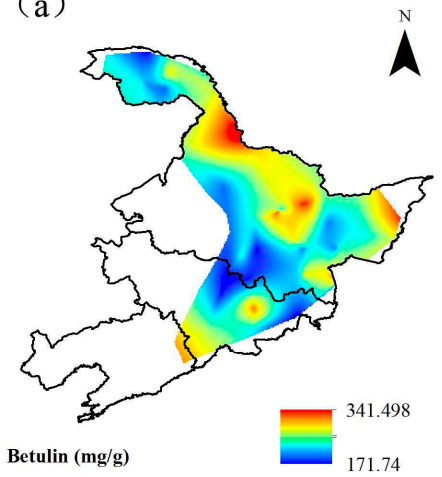

(b)

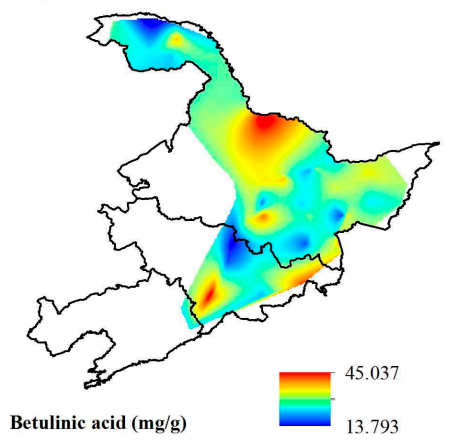

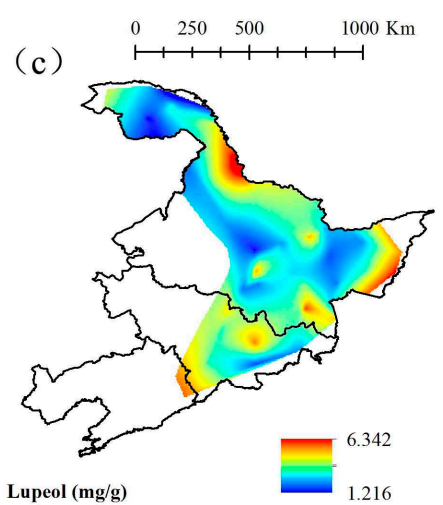

Figure 3. Spatial distributions of concentrations of three triterpenoids of betulin (a); betulinic acid (b) and lupeol (c) in barks of white birch trees from 48 sampling plots in Northeast China.

\subsection{The Relationship Between Climatic Factors and Concentrations of BTB Triterpenoids}

None of geographical indices of latitude, longitude nor elevation were detected to have significant correlation with either of three triterpenoids' concentrations (Table 3). Also, all three geographical indices were treated as excluded variables from the stepwise regression model. Stepwise correlation analysis indicated that the model with precipitation accounted for $12.1 \%$ of variation in data of betulin concentrations $(F=6.307, p=0.016)$. Another stepwise correlation analysis indicated that the model with temperature and relative humidity together accounted for $37.3 \%(F=13.394, p<0.001)$ of variation in data of lupeol concentrations. None of the explanatory variables about climatic factors were able to be entered into any model explaining variation of data of betulinic acid concentrations at the probability level of 0.05 by stepwise regression analysis.

Table 3. $R$ values from correlation between concentrations of three triterpenoids (betulin, betulinic acid and lupeol) in white birch trees and climate factors in Northeast China $(n=48)$.

\begin{tabular}{cccc}
\hline Geographical and Climatic Indices & Betulin $\left(\mathbf{m g ~ g}^{-\mathbf{1}}\right)$ & Betulinic Acid $\left(\mathbf{m g ~ g}^{-\mathbf{1}}\right)$ & Lupeol $\left(\mathbf{m g ~ g}^{-\mathbf{1}}\right)$ \\
\hline & Pearson correlation & & \\
Latitude $\left({ }^{\circ}\right)$ & 0.001 & -0.135 & -0.230 \\
Longitude $\left({ }^{\circ}\right)$ & 0.220 & 0.127 & 0.220 \\
Elevation $(\mathrm{m})$ & -0.103 & -0.079 & -0.221 \\
Temperature $\left({ }^{\circ} \mathrm{C}\right)$ & $0.332^{*}$ & 0.243 & $0.540^{* * *}$ \\
Humidity $(\%)$ & $-0.323^{*}$ & 0.066 & $-0.493^{* * *}$ \\
Precipitation $(\mathrm{mm})$ & $0.347^{*}$ & 0.031 & $0.495^{* * *}$ \\
& Spearman correlation & & -0.220 \\
Latitude & 0.046 & -0.064 & 0.181 \\
Longitude & 0.214 & 0.140 & -0.215 \\
Elevation $(\mathrm{m})$ & -0.138 & -0.051 & $0.541^{* * *}$ \\
Temperature $\left({ }^{\circ} \mathrm{C}\right)$ & $0.314^{*}$ & 0.146 & $-0.3944^{* *}$ \\
Humidity $(\%)$ & -0.238 & 0.047 & $0.342^{*}$ \\
Precipitation $(\mathrm{mm})$ & 0.192 & -0.031 & \\
\hline
\end{tabular}

* Correlation is significant at 0.05 level (two-tailed); ** Correlation is significant at 0.01 level (two-tailed); $* * *$ Correlation is significant at 0.001 level (two-tailed). 
Climatic indices of temperature and precipitation had positive correlation with concentrations of betulin and lupeol, while humidity had negative correlation with concentrations of these two triterpenoids (Table 3). Both temperature and precipitation had positively linear relationships with betulin concentration, and the slope for temperature was higher than that for precipitation (Figure $4 \mathrm{a}, \mathrm{c}$ ). Relative humidity had a negative linear relationship with betulin concentration (Figure $4 \mathrm{~b}$ ). Both temperature and relative humidity had significant correlations of exponential growth with lupeol concentration, but the former correlation was positive while the later was negative (Figure $4 a, b$ ). Precipitation had a positive linear correlation with lupeol concentration (Figure 4c), although its slope was about one third of that in the correlation between precipitation and botulin.
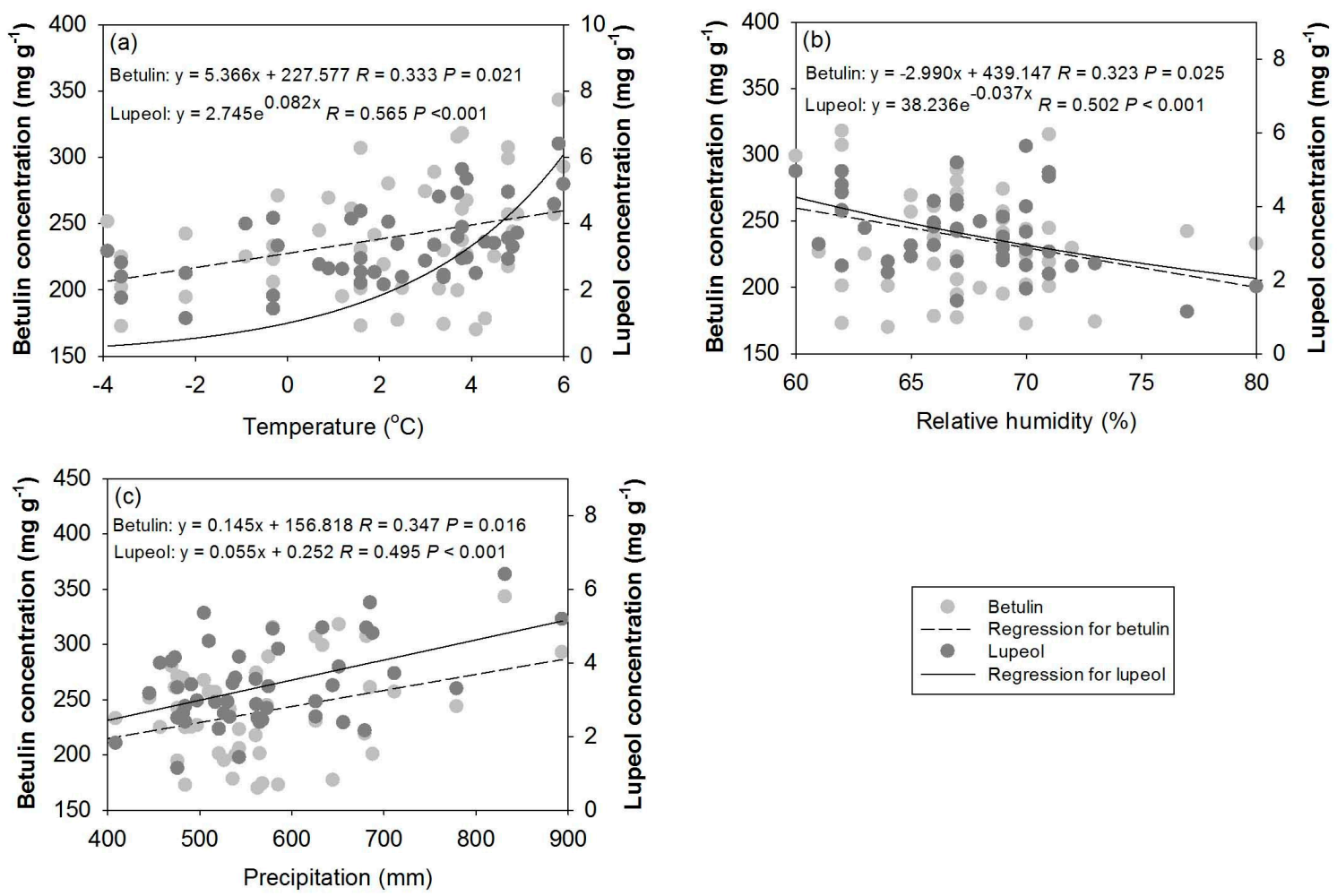

Figure 4. Regressions between climatic factors of temperature (a); relative humidity (b) and precipitation; (c) and betulin and lupeol concentrations in barks of white birch trees in Northeast China $(n=48)$.

\section{Discussion}

Thus our data were insufficient to report soil characteristics which have a strong effect on secondary metabolites production in montane trees. However, former studies revealed that soil inorganic carbon (C) ranged between $0.5-2 \mathrm{~kg} \mathrm{~cm}^{-2}$, soil organic $C$ ranged between $0.35-2.42 \mathrm{~kg} \mathrm{~cm}^{-2}$, and the distribution of both these parameters had the least variation in all of the national territory of mainland China [22,23]. In addition, other soil properties, such as $\mathrm{N}$ content and $\mathrm{pH}$ value, were all well correlated with soil $C$ storage in our study region, which were all concentrated in a given range without large variation of data [24].

The average of our betulin concentration was $80 \%$ higher than that of birch trees of the Western Carpathians (101.82-165.60 $\mathrm{mg} \mathrm{g}^{-1}$ ) [14], and 113\% higher than that of other studies in Northeast China (113-202 $\mathrm{mg} \mathrm{g}^{-1}$ by Zhao et al. [1]; 22.02-29.52 $\mathrm{mg} \mathrm{g}^{-1}$ by Wang et al. [6]). However, our betulin concentration was only about one third of that in barks of birch (Betula pendula Roth.) trees in Russia using a new extraction procedure [2]. The value of betulinic acid concentration in our study was about 10 times of that (2.08-2.70 $\left.\mathrm{mg} \mathrm{g}^{-1}\right)$ in Wang et al. [6] and two times of that in Holonec et al. [14] 
(11.15-14.68 $\mathrm{mg} \mathrm{g}^{-1}$ ) and Zhao et al. [1] (12.2-18.6 $\mathrm{mg} \mathrm{g}^{-1}$ ). Our lupeol concentration was comparable with that (2.7-5.0 $\left.\mathrm{mg} \mathrm{g}^{-1}\right)$ of Popov et al. [2], although authors therein employed an extractant recycle. According to our results, high concentration of betulin in our study can be determined by regional climatic factors which together contribute to the natural synthesis and accumulation of betulin compounds. The relatively higher concentration of betulin acid in our study than others' was because betulinic acid is the oxidation product of botulin. Recent studies reported that lupeol can also be converted from betulin [25]. Therefore, the abundant reserve of betulin may also be the precondition of lupeol accumulation in white birch trees in Northeast China.

Former studies have indicated that concentrations of triterpenoids in BTB can change strikingly depending on the location and resulting geographically distribution patterns with different concentrations $[1,14]$. In the forest areas of the Western Carpathians, the betulin concentration in BTB was found to be highest in the western part and declined in the east, while the betulinic acid concentration was found to be highest in the central part and lower in the surrounding parts [14]. In another area in Northeast China, Zhao et al. found both declines of betulin and betulin acid concentrations from the north to the south across general data from provinces [1]. The distribution pattern of betulin concentration in our study concurs with others in the Western Carpathians [14] if data from northern sites in Jilin Provinces were excluded from the database (Figure 3). However, our distribution pattern of betulinic acid concentrations agreed with the one in Holonec et al. [14]. In contrast, none of our distribution patterns were similar to those found by Zhao et al. [1]. The most likely explanation of difference of triterpenoid concentrations in BTBs among studies was sampling intensity. Our sampling site number $(n=48)$ was much higher than that in Holonec et al. [14] $(n=10)$ and Zhao et al. [1] ( $n=3)$; hence, our results regarding geographical distribution were more reliable.

Studies reported that birch trees can respond to geographical gradient [26,27]. Kozlov found that with the increase of latitude degree herbivory-caused loss of leaf area in B. pubescens decreased [26]. Stark et al. reported that foliar quercetin concentration in B. pubescens increased with latitude [27]. Although we did not find any trend of changes of BTB triterpenoid concentration along geographical gradients, our results concur with the response of B. pendula [26]. Climatic factors also contributed to significant correlations with birch tree responses even when the response to geographical gradient was significant $[26,27]$. It seems that birch response to geographical gradients was mainly driven by climatic factors. For example, geographical changes of foliar quercetin in birch trees were formed by the change of UV radiation along the gradient; this is because flavonoid compounds can protect plant leaves from phytotoxic levels of radiation by absorbing UV radiation, while simultaneously transmitting the photosynthetically active radiation to the chloroplasts [27]. Therefore, the null response of triterpenoid concentration to geographical response in our study was because the changes of climatic factors were not significant enough to drive the change of triterpenoid concentration in birch trees.

In our study, the increases of betulin and lupeol concentrations to temperature (Figures $3 a$ and $4 a$ ) were because high temperature can trigger the synthesis of triterpenoid to prevent thermal damage [18]. In addition, Kylin et al. considered that the increase of terpene content in pine needles during summers with elevated temperature may counteract the volatilization [28]. In contrast, low temperatures can negatively impact the accumulation of triterpenoids [19]. In Northeast China, air temperature tends to elevate sharply beginning in early May, and temperature usually begins to decline in late August. Our results indicate that most of the summer time locally during June and July may be proper to harvest triterpenoids in BTB due to significant increase of accumulation. The low relative humidity can cause a drought event which can promote the synthesis of triterpenoids $[17,20]$. Therefore, the negative relationship between relative humidity and betulin and lupeol concentrations (Figures $3 b$ and $4 b$ ) may be shaped by the drought level. It is surprising that precipitation resulted in a positive relationship with triterpenoid concentration. To our knowledge, very little evidence can be found to illustrate this relationship. However, we found that temperature had a positive relationship with precipitation (Pearson correlation, $R=0.621, p<0.0001$ ). Most likely, the regions in our study contributing to the most 
proportion of regional rainfall located in the southern part of the study area. As a result, the relationship between precipitation and triterpenoid concentration was mostly affected by regional temperature.

\section{Conclusions}

Concentrations of triterpenoids (betulin, betulinic acid and lupeol) in the barks of white birch trees did not change in response to any geographical gradients of latitude, longitude and elevation. Instead, the triterpenoid concentration was significantly correlated with climatic factors of temperature, relative humidity and precipitation. More specifically, concentrations of betulin and lupeol in BTBs increased with the elevation of temperature and precipitation, but declined with the increase of relative humidity. As a result, betulin concentration was higher in birch trees in the northeastern and southwestern parts of the study area and lower in the central part of the study area in Northeast China. Although betulinic acid concentration did not change with climatic factors, its distribution pattern was similar with betulin concentration. Lupeol concentration in barks of white birch trees was higher in the northeastern part of the study area and along the southern and eastern boundaries of the study area. Our results can supply information for precondition of triterpenoids' extraction for industrial production, which can be an available approach to solve the issue of bark waste processing of white birch. However, we failed to find the response of triterpenoids to geographical gradients. This may be because our sites were not located in absolute geographical gradients. Further studies are recommended to be carefully designed to make the distribution of sampling sites more likely along the geographical gradient. Alternatively, climatic factors should be pre-investigated before the collection so as to make the change of environmental parameters more significant along the geographical gradient.

Acknowledgments: This research was financially supported by the National Key Research and Development Program of China (2016YFC0500300), the Forestry Industry Research Special Fund for Public Welfare (201004069) and the Fundamental Research Funds for the Central Universities (DL13EA02), the National Natural Science Foundation of China (31600496) and The National Key Research and Development Program of China (2016YFC0500307).

Author Contributions: Shenglei Guo and Xiufeng Yan designed the experiment; Shenglei Guo, Dehui Zhang, Huanyong Wei, Yinan Zhao and Yibo Cao together set study sites, collected barks, drew the distribution images; Shenglei Guo, Tao Yu and Yang Wang determined triterpenoid concentrations and wrote the initial edition of manuscript; Xiufeng Yan revised the manuscript.

Conflicts of Interest: The authors declare no conflicts of interest. The funding sponsors had no role in the design of this study; in the collection, analyses, or interpretation of data; in the writing of the manuscript; or in the decision to publish the results.

\section{References}

1. Zhao, G.L.; Yan, W.D.; Cao, D. Simultaneous determination of betulin and betulinic acid in white birch bark using RP-HPLC. J. Pharmaceut. Biomed. 2007, 43, 959-962. [CrossRef] [PubMed]

2. Popov, S.A.; Sheremet, O.P.; Kornaukhova, L.M.; Grazhdannikov, A.E.; Shults, E.E. An approach to effective green extraction of triterpenoids from outer birch bark using ethyl acetate with extractant recycle. Ind. Crop. Prod. 2017, 102, 122-132. [CrossRef]

3. Drag-Zalesińska, M.; Drag, M.; Poręba, M.; Borska, S.; Kulbacka, J.; Saczko, J. Anticancer properties of ester derivatives of botulin in human metastatic melanoma cells (Me-45). Cancer Cell Int. 2017, 17, 4. [CrossRef] [PubMed]

4. Fuchino, H.; Konishi, S.; Satoh, T.; Yagi, A.; Saitsu, K.; Tatsumi, T.; Tanaka, N. Chemical evaluation of Betula species in Japan. II. Constituents of Betula platyphylla var japonica. Chem. Pharm. Bull. 1996, 44, 1033-1038. [CrossRef]

5. Patočka, J. Biologically active pentacyclic triterpenes and their current medicine significance. J. Appl. Biomed. 2003, 1, 7-12.

6. Wang, S.; Zhao, H.; Jiang, J.; Liu, G.F.; Yang, C.P. Analysis of three types of triterpenoids in tetraploid white birches (Betula platyphylla Suk.) and selection of plus trees. J. For. Res. 2015, 26, 623-633. [CrossRef] 
7. Yin, J.; Ren, C.L.; Zhan, Y.G.; Li, C.X.; Xiao, J.L.; Qiu, W.; Li, X.Y.; Peng, H.M. Distribution and expression characteristics of triterpenoids and OSC genes in white birch (Betula platyphylla Suk.). Mol. Biol. Rep. 2012, 39, 2321-2328. [CrossRef] [PubMed]

8. Krasutsky, P.A. Birch bark research and development. Nat. Prod. Rep. 2006, 23, 919-942. [CrossRef] [PubMed]

9. Szuster-Ciesielska, A.; Kandefer-Szerszeń, M. Protective effects of betulin and betulinic acid against ethanol-induced cytotoxicity in HepG2 cells. Pharmacol. Rep. 2005, 57, 588-595. [PubMed]

10. Recio, M.C.; Giner, R.M.; Mánez, S.; Ríos, J.L. Structural requirements for the anti-inflammatory activity of natural triterpenoids. Planta Med. 1995, 61, 182-185. [CrossRef] [PubMed]

11. Gong, Y.H.; Raj, K.M.; Luscombe, C.A.; Gadawski, I.; Tam, T.; Chu, J.H.; Gibson, D.; Carlson, R.; Sacks, S.L. The synergistic effects of betulin with acyclovir against herpes simplex viruses. Antivir. Res. 2004, 64, 127-130. [CrossRef]

12. Pavlova, N.I.; Savinova, O.V.; Nikolaeva, S.N.; Boreko, E.I.; Flekhter, O.B. Antiviral activity of betulin, betulinic and betulonic acids against some enveloped and non-enveloped viruses. Fitoterapia 2003, 74, 489-492. [CrossRef]

13. Muceniece, R.; Saleniece, K.; Rumaks, J.; Krigere, L.; Dzirkale, Z.; Mezhapuke, R.; Zharkova, O.; Klusa, V. Betulin binds to $\gamma$-aminobutyric acid receptors and exerts anticonvulsant action in mice. Pharmacol. Biochem. Behav. 2008, 90, 712-716. [CrossRef] [PubMed]

14. Holonec, L.; Ranga, F.; Crainic, D.; Truta, A.; Socaciu, C. Evaluation of betulin and betulinnic acid content in birch bark from different forestry areas of Western Carpathians. Not. Bot. Horti Agrobot. Cluj-Napoca 2012, 40, 99-105.

15. Laghari, A.H.; Memon, S.; Nelofar, A.; Khan, K.M. Alhagi maurorum: A convenient source of lupeol. Ind. Crop. Prod. 2011, 34, 1141-1145. [CrossRef]

16. Hassegawa, M.; Stevanovic, T.; Achim, A. Relationship between ethanolic extracts of yellow birch and tree characteristics. Ind. Crop. Prod. 2016, 94, 1-8. [CrossRef]

17. Yin, J.; Liang, T.; Wang, S.Y.; Zhang, M.Y.; Xiao, J.L.; Zhan, Y.G.; Li, C.X. Effect of drought and nitrogen on betulin and oleanolic acid accumulation and OSC gene expression in white birch saplings. Plant Mol. Biol. Rep. 2015, 33, 705-715. [CrossRef]

18. Schuster, A.C.; Burghaardt, M.; Alfarhan, A.; Bueno, A.; Hedrich, R.; Leide, J.; Thomas, J.; Riederer, M. Effectiveness of cuticular transpiration barriers in a desert plant at controlling water loss at high temperature. AOB Plant 2016, 8, plw027. [CrossRef] [PubMed]

19. Zhao, Z.J.; Song, Y.G.; Liu, Y.L.; Qiao, M.; Zhai, X.L.; Xiang, F.N. The effect of elicitors on oleanolic acid accumulation and expression of triterpenoid synthesis genes in Gentiana straminea. Biol. Plantraum 2013, 57, 139-143. [CrossRef]

20. Nasrollahi, V.; Mirzaie-asl, A.; Piri, K.; Nazeri, S.; Mehrabi, R. The effect of drought stress on the expression of key genes involved in the biosynthesis of triterpenoid saponins in liquorice (Glycyrrhiza glabra). Phytochemistry 2014, 103, 32-37. [CrossRef] [PubMed]

21. China Meteorological Data Service Center. Available online: http://data.cma.cn/en/?r=site/index (accessed on 5 June 2017).

22. Wu, H.B.; Guo, Z.T.; Gao, Q.; Peng, C.H. Distribution of soil inorganic carbon storage and its changes due to agricultural land use activity in China. Agric. Ecosyst. Environ. 2009, 129, 413-421. [CrossRef]

23. Zhou, R.; Pan, X.Z.; Wei, H.X.; Xie, X.L.; Wang, C.K.; Liu, Y.; Li, Y.L.; Shi, R.J. Soil organic carbon stocks in terrestrial ecosystems of China: Revised estimation on three-dimensional surfaces. Sustainability 2016, 8, 1003. [CrossRef]

24. Chen, C.H.; Chen, X.J.; Niu, J.L.; He, Z.Y. Analysis of spatial distribution and main controlling factors of soil organic carbon content and total nitrogen content in Northeast China. J. Arid Land Resour. Environ. 2015, $29,3$. (In Chinese with English abstract) [CrossRef]

25. Liu, S.Y.; Xu, F.; Liu, L.J.; Ma, D.Y. A convenient synthesis of lupeal from betulin. Ind. Crop. Prod. 2015, 74, 494-496. [CrossRef]

26. Kozlov, M.V. Losses of birch foliage due to insect herbivory along geographical gradients in Europe: A climate-driven pattern? Clim. Chang. 2008, 87, 107-117. [CrossRef] 
27. Stark, S.; Julkunen-Tiitto, R.; Holappa, E.; Mikkola, K.; Nikula, A. Concentrations of foliar quercetin in natural populations of white birch (Betula pubescens) increase with latitude. J. Chem. Ecol. 2008, 34, 1382-1391. [CrossRef] [PubMed]

28. Kylin, H.; Söderkvist, K.; Undeman, A.; Franich, R. Seasonal variation of the terpene content, an overlooked factor in the determination of environmental pollutants in pine needles. Bull. Environ. Contam. Toxicol. 2002, 68, 155-160. [CrossRef] [PubMed]

2017 by the authors. Licensee MDPI, Basel, Switzerland. This article is an open access article distributed under the terms and conditions of the Creative Commons Attribution (CC BY) license (http://creativecommons.org/licenses/by/4.0/). 